\title{
Supervision in Contemporary and Democratic Education ${ }^{1}$
}

\author{
Yrd. Doç. Dr. Tuncay ÖZDEMIR* \\ Abant İzzet Baysal Üniversitesi, Eğitim Fakültesi, Gölköy Kampüsü, Bolu / Türkiye

\section{Prof. Dr. H. Nihat BİLGEN} \\ Abant İzzet Baysal Üniversitesi, Eğitim Fakültesi, Gölköy Kampüsü, Bolu / Türkiye
}

\begin{abstract}
The purpose of this study is to analyse and interpret the consultancy, guidance, examine-research and control functions of supervision within the frame of contemporary and democratic education and to make relevant suggestions. This is a review study based on the related literature. Contemporary and Democratic Education Theory builds up the subject and theoretical basis of the study. Supervision is the administrative sub-system assigned to carry out general purposes of Turkish National Education. Education raises future individuals through current understanding and methods. Current inputs and process variables will affect future citizens of Turkey. Students are in the centre of education process. Supervision functioning in the

\footnotetext{
${ }^{1}$ This study is produced from doctoral dissertation named "Supervision in Contemporary and Democratic Education" done under the supervision of Prof. Dr. H. Nihat BILGEN at the Department of Educational Administration and Supervision in Abant Izzet Baysal University.

* Sorumlu Yazar.

Tel: +90 3742541660

E-posta: ozdemir_t@ibu.edu.tr

(C) 2016 Kalem Eğitim ve Sağlık Hizmetleri Vakfı. Bütün Hakları Saklıdır.

ISSN: 2146-5606
} 
structure and processes directly reflects on students. It is hoped that supervisors should understand students properly in terms of their cognitive, affective, and psychomotor differences, and exemplify right behaviours. To conclude, it is expected supervisors should display contemporary and democratic thinking and behaviours, adopt these in their lives, and ensure that educational purposes realize through supervision functions.

Keywords: Contemporary and democratic education; Supervision; Supervision in contemporary and democratic education.

\section{Çağdaş ve Demokratik Ĕgitimde Teftiş}

\section{$\ddot{\mathbf{O} z}$}

Bu çalışmanın amacı, Çağdaş ve Demokratik Eğitim çerçevesinde, teftişin danışmanlık rehberlik, inceleme-araştırma ve kontrol işlevlerini analiz etmek, yorumlamak ve önerilerde bulunmaktır. Çalışma, alanyazın taramasına dayalı derleme türünde yapılmıştır. Çalışmanın konusunu ve kuramsal temelini, Bilgen'in Çağdaş ve Demokratik Eğitim Kuramı oluşturmuştur. Teftiş, Türk Millî Eğitiminin genel amaçlarını gerçekleştirmekle görevli, yönetim alt sistemidir. Eğitim, bugünün anlayış ve yöntemleri ile geleceğin insanını yetiştirir. Geleceğin ülke insanını, bugünün Türk millî eğitim sisteminin girdileri ve süreç değişkenleri etkileyecektir. Eğitim sürecinin merkezindeki bugünün öğrencisidir. Teftişin, yapı ve süreçlerde doğrudan görev yapması dolaylı olarak öğrenciye yansır. Teftiş sisteminde görevli müfettişlerin, öğrenciyi bilişsel, duyuşsal ve psikomotor farklılıklar bağlamında doğru algılaması ve işlevlerini yerine getirmede doğru davranışları örneklemesi beklenir. Sonuç olarak, müfettişlerin, çağdaş ve demokratik düşünüş ve davranışlar göstermesi, bunu hayat felsefesi haline getirmesi; işlevler yoluyla da amacin gerçekleşmesine yöneltmesi beklenir.

Anahtar Kelimeler: Çăgdaş ve demokratik eğitim; Teftiş; Çağdaş ve demokratik eğitimde teftiş. 


\section{Introduction}

The principal purpose of education is to raise virtuous individuals, and the second purpose is to gain individuals scientific behaviours. Undoubtedly, "Scientific behaviour can only develop in a setting where freedom of belief, and freedom of enterprise exist, and where science is valued." (Bilgen, 1993). Democracy requires individuals to be virtuous and to behave democratically. In general, schools exemplify the society. A democratic society can only be created when educational settings are equipped with contemporary and democratic stimulants, supervisors, administrators, and teachers possess contemporary and democratic behaviours, children live in such a setting, and develop contemporary and democratic behaviours. A society can be contemporary and democratic only if education institutions function and people live and behave accordingly.

The duty of National Ministry of Education is to realize the general objectives of Turkish National Education. Directorate for guidance and Supervision, and Directorate for Education Supervisors operate to realize the objectives of Turkish National Education in education institutions. Supervisors who work for these directorates should have contemporary and democratic behaviours. Supervision behaviours should also involve all these qualities to carry out functions of consultancy, guidance, examination-research, control and investigation.

The principal duty of schools is to raise contemporary and democratic individuals and to create a democratic society. Supervision should gain vision and dynamism to this understanding.

What is virtuous for a slave is to obey the powerful. Contemporaneousness means commitment to human rights and democracy, openness to scientific developments and productivity in scientific fields, and requires individuals who have exhibit scientific behaviours virtuously. Creating a society composed of virtuous and wise individuals, and raising people with scientific behaviours can only be possible through a contemporary and democratic education process.

Supervisions functions as a bridge between the school administrator and teacher with regard to their functions to realize the objectives of Turkish National Education, passes science process into schools, and contributes to 
administrators and teachers' motivation and productivity. It is expected that supervision should be contemporary and democratic during these processes. Supervision behaviour reflects on students via school administrators and teachers.

The purpose of this study is to analyse and interpret the consultancy, guidance, research-examine and control functions of supervision within the frame of contemporary and democratic education and to make suggestions. This is a compile study based on literature review. Investigation function of supervision was not included within this study. Investigation function and their functions are different. The difference is that the supervisor as an investigator works as an attorney whereas in other functions she/he uses her/his own professional competency.

\section{Contemporary and Democratic Education}

Contemporary education is defined as "science, technology, art and values of the era qualify cognitive, affective and psycho-motor stimulants of the education setting.", and democratic education is stated as "human rights and principles of democracy are a way of living in the education setting." (Bilgen, 1996, p.3).

Today, "literacy" is defined as the competency and skill of producing, using and benefiting from contemporary instruments. Turkish people have the intelligence potential to realize and move beyond these. Being contemporary is in a way perceiving the era.

The statement of Russel (2001, p.28) "the majority of children have the potential of being either a good citizen or a criminal" emphasizes that good or evil can easily cultivate in children. Bilgen (1986, p.2) states that "Indeed the most realistic and correct implementation of respect to an individual is to take care to her/his education."

Main principles of Bilgen's Contemporary and Democratic Education Theory are the theoretical basis of this study. These principles are as follows (Bilgen, 1993, p.19):

1. Every individual has the right to education. Every individual is given education opportunity. Children with disabilities and children without disa- 
bilities educate in same classrooms whenever possible. Everyone can receive higher education. Everyone can be successful.

2. Education is a student-centred process. Education is organised in accordance with each student's interests, aptitudes, and abilities. Individual differences are considered.

3. Everyone can be successful in accordance with their potential. Success depends on a student's power of learning, readiness, and motivation.

4. Every student is responsible for her/his on education and authorized to choose the curriculum (courses). Courses are for students, not the vice versa. All courses in elementary schools are elective. A student can take as many courses as she/he wants until completing the required credit.

5. Measurement and evaluation is a tool that ensures students to be successful and prepare for the future. Grades (unless standard) should be removed.

6. Student's achievements (outside the class, school or country) appropriate for program objectives are assessed. If one or more courses in the curriculum are completed by the student outside the school, she/he is exempted from these courses.

7. Instead of threat and fear, love and respect sanctions are used. Teacher loves all students. Student can leave the classroom when she/he wants, and act freely without disturbing the others in the class. Fear, threat, and punishment are not proper educational tools.

8. Longitudinal and horizontal transfer ways between types and levels of education are free. Student can take any course which he/she desires from any school which he/she selects (or even from abroad through internet).

9. Education prepares individuals for the future. The duty of education is to prepare children for the future.

10. Structures and behaviours of educational institutions should be in accordance with the human rights and principles of democracy. Matters stated in the all 30 articles of Universal Declaration of Human Rights form the 
grounds of educational settings. Student has the right to choose his/her teacher. Teachers choose school principle.

\section{Supervision and its Functions in Contemporary and Democratic Educa- tion}

Many definitions of supervision have been found in the literature. According to Caroll supervision "a way of life, a value system that drives us as much personally as it does professionally." (Henderson, 2009a). Henderson (2009b) have defined supervision as a practical and useful activity of vital importance that is observational and provides feedback. Supervision can also be defined as observing work of others to provide satisfactory performance by using authority. Supervision has three primary functions: educational, administrative, and supportive (Caspi and Reid, 2012, p.2; Evans, 2009, p.2), and it focuses on learners, teachers, and school administrators (Caspi and Reid, 2012, p.2). Educational supervision incorporates in hierarchical and evaluative concepts (Evans, 2009: 2). Supervision and evaluation play important key roles in enhancing work performance (Marshall, 2013, p.19).

Burke and Krey (2005, p.20-22) define supervision as instructional leadership and according to this view:

1. Personal views affect behavioural choices.

2. Definition, identification, and participation are essential for accepting and understanding of objectives.

3. Supervision is a contributory and a supportive action.

4. Human interactions need to be facilitated and coordinated.

5. Enhancing and continuity successes depend on analysis and appraisal.

6. Determination of objective development, progress and success needs a productive enterprise.

In this context, a supervisor develops the relationship of behaviour and point of view, focuses on targets, contributes to and helps organizational activities, coordinates interactions, ensures enhancing and continuity of educational programs, and evaluates target successes (Burke and Krey 2005, 
p.21-22). This statement points out the guidance role of the supervisor which should highlight her/his functional authority.

Ferguson (2005) states that "professional supervision is a process between someone called a supervisor and another referred to as the supervisee. It is usually aimed at enhancing the helping effectiveness of the person supervised. It may include acquisition of practical skills, mastery of theoretical or technical knowledge, personal development at the client/therapist interface and professional development." (Cited in Davys and Beddoe, 2010, p.10).

Supervision is to observe the ways how staff in an organization perform their duties, to reveal errors and deficiencies, to take necessary precautions to correct them, and to introduce innovations and develop methods in solving the organizational problems. Supervision requires a supervisor to work as an administrator, leader, mentor, teacher, and researcher (Taymaz, 1993, p.23).

Supervision activities influence the way, rate and quality of change (Harris, 1975, p.35). It has a supportive role in organizational development. It helps to develop better teaching and learning situations. A good supervisor has a supporting, helping, and sharing role rather than a dominating role. It is a service activity in order to help teachers perform their duties better. The function of a supervisor in a school is to help teachers to realize their whole potential (Wiles, 1963, p.8-11).

Aydin (1993, p.11-18) explained the characteristics of supervision in the contemporary education as below;

The purpose is to develop the process of learning and teaching. The quality of existing and detected problem, features and conditions of the setting determine the purpose and method. It depends on cooperation; it is scientific and motivational; it is both analytic and unifier; it is directed to both past and future. Supervision involves democratic leadership. The starting point in supervision is the existing structure and conditions. In contemporary educational supervision, flexibility principle is applied; teachers are given the opportunity to prove themselves; there is an order and continuity in its program; individual differences are esteemed; positive human relationship approach is fol- 
lowed; interaction is important; consensus and a continual research tradition are believed to be important for the success.

In the traditional point of view, supervision is the process of control and assessment whereas in the contemporary view, it is the guidance and development process (Memduhoğlu and Zengin, 2012, p.134).

According to the decree law about the National Ministry of Education organization and its functions promulgated in the 28054 issue of Turkish Official Gazette on September 14, 2011, Directorate for Guidance and Supervision is included within the central organization structure. Directorate for Guidance and Supervision and Directorate for Education Supervisors of National Ministry of Education were promulgated in the 29009 issue of Turkish Official Gazette on May 24, 2014. Then, regulations related to making amendments on the aforementioned regulations were promulgated in the 29655 issue of Turkish Official Gazette on March, 16 2016. According to the first regulation, Directorate for Guidance and Supervision is appointed with the command and approval of the Minister (article 8-i), and Directorate for Education Supervisors is appointed with the approval of Provincial Director of National Education (article 46-i).

In this study consultancy, guidance, examine-research and control functions of supervision within the context of contemporary and democratic education has been investigated.

\section{Consultancy}

Consultancy is to inform top director by the supervisor in accordance with his/her needs based on the data obtained from the supervision process to realize the goals of Turkish National Education. According to Bilgen, supervision generally has the characteristics of a consultancy service. Supervisor, due to his/her closeness to the decision-making organ, can lead the execution related to the practice by using the functional authority as a field of expert (Bilgen, 2011, p.271). The source of functional authority is the cognitive competencies of supervisor.

Supervisor is an expert who creates options and presents these to decision makers by using her/his own capabilities and combining her/his own 
experience and observations in practice based on the theories of administrative science.

Consultancy function of supervisors is a duty they serve to higher directors. Supervisor is not a decision maker, but is an employee who creates options based on her/his own competencies.

Supervisor provides data to directors about which staff would be more useful in which position. Supervison can operate as a channel in communication. Affect is the process of mobilizing group members around the organizational goals to accomplish them. Punishments, rewards, and in-service training are used for the affect. For this purpose, higher administrator is consulted. Supervisor is the one who makes decision options, scientific and practical data meaningful.

Supervision should provide solutions to the decision-organ about the causes of abnormal behaviours of children.

Supervision should find solutions and inform the higher administration on the absences and defects of school buildings that may pose a threat to human life and need emergent precautions.

\section{Guidance}

"Every organization is founded to accomplish certain goals. All actions and procedures in the organization are valued in line with their contributions to realize these goals." (Bilgen, 2011, p.271). In this context, education, production, and administration organizations can reach their targets using scientific methods rather than past experiences. (Bilgen, 2011, p.259).

Guidance task is one of the most valuable functions which prevents deviations from the aims, increases quality in education and teaching and brings norms and standards to shape the product. Guidance task requires a supervisor be updated consistently in terms of field knowledge. This function plays a great role in transferring scientific and technological developments to education system. (Bilgen, 1990, p.9). 
Participation of supervisor in the decision-making process increases the effect. Supervisor equipped with guidance task transmits the decisions to the related people.

Supervision should give guidance to students in terms of how to use tools better, using physical resources and financing, assessment (about assessment standards and systems) and understanding purposes better.

The main purpose of guidance regarding administrators and teachers is "to develop teaching-learning process. This purpose requires observation and improvement of all activities carried out in education settings in a planned and programmed way." (Seçkin, 1998, p.209).

Supervision should guide administrators and teachers regarding the precautions to protect children from gaining bad habits. Problems should be approached and solved in line with democratic rules.

\section{Examine-Research}

The first dimension of examine-research task involves observing, watching, learning and second dimension involves scientific curiosity and scientific production. Supervisor, while creating options for the decision organ in line with these dimensions, guides administrators and teachers. The following statement of Bilgen is remarkable:

Supervisor is a member of administrative staff who observes structures and behaviours of education institutions closely, establishes the correspondence between problems of application and theory-application, and as a field of expert carries out investigations and research that can contribute to the development of the system and processes. (Bilgen, 2011, p.271).

"This function includes the stages of defining the problem, developing hypothesis, and producing solutions by theoretical and practical trials." (Bilgen, 2011, p.259).

"Carrying out the examination and research duty depends on scientific research competencies of supervisors." (Bilgen, 1990, p.123). 
"In order for the educational practices to follow the contemporary developments, competencies of supervisors should be refreshed continuously." (Bilgen, 1990, p.56).

Because the theoretical developments in administrative science form the theoretical structure of supervision, contemporary supervisor has to continuously follow the administration science, examine, and make research, and benefit from research studies. Though this duty is significant in terms of producing and following contemporary and democratic education, however in case of its absence, it is not possible to catch up with the era.

Existence of behaviours deviate from the norms for administrators, teachers and students means either the norm has changed or there is a serious problem. Thus, behaviour analysis should be done.

\section{Control}

It is the duty of supervisors to control the educational process, product, and variables. Supervisor should perform the control task related with the realization levels of educational goals, actions taken for the sake of being a democratic, secular, and social state, behaviours deviating from these goals, functions that are not goal-directed, actions directed towards personal purposes and whether they are realized or not, and problems occurred from the structural dimension.

Aseltine, Faryniarz and Rigazio-DiGilio (2006, p.12-24) emphasize the need for a different paradigm to evaluate teachers, becasuse:

1. Shifting of the focus of education from teaching centred to student learning

2. Increasing accountability and gaining persistance.

3. Focusing of developments in education literature and professional field on data-based decision making.

4. Focusing of traditional models of supervision and assessment on the process of teacher's work rather than the work output.

5. Importance given to conventionalism in the teaching processes limits teachers' professional development. 
6. Conventional teacher supervision and assessment cannot connect clearly establish the bond between teaching and learning or provide different teaching content.

7. Conventional methods in evaluating teachers cannot help teachers to make a direct connection between professional development, standard assessment results and students' learning needs addressed by the school development plan.

Bilgen points out the control function and emphasizes that:

"In the goal dimension, realization of the goal is essential. In the assessment, to what extent the goal has been realized is considered. Assessment is to determine the value of behaviour by comparing it with standard criteria." (Bilgen, 1997).

"In a large system like educational system which involves many variables, establishing and operating a control sub-system which will provide the structures and behaviours that will realize the goals at an optimal level is vitally important." (Bilgen, 2011, p.271).

"Each assessment should depend on measurement, and the measurement should be standard. Assessment is the expression of measurement results with a value judgment. The most difficult assessment is the staff assessment. Assessment should be conducted in critical times, not in normal times." (Bilgen, 1997).

It is important for an individual to assess herself/himself and her/his environment in order to predict her/his future. Experiment and observation are pretty much seem to be in the laboratory, however experiment can also be carried out in the cognitive domain (Bilgen, 1997).

According to Bursalığlu (1994, p.128), the purpose of assessment is to determine the degree of success of an application in an unbiased way. Research is done before the assessment and then reorganizations are made. In order for assessment to be unbiased, assessment criteria should be prepared before the application. "Assessment is a mutual interaction between the assessor and the assessed." 
Supervision controls whether or not the organization serve purposes of other organizations, and whether or not administrators and teachers use their authorities in line with the purposes.

Supervision controls efficiency (success state) of schools and determines precautions to give consultancy to senior management, and provide guidance to administrators and teachers.

It is the duty of a supervisor to check the clarity of purposes for administrators and teachers in schools.

A supervisor develops appropriate supervision behaviours in a contemporary and democratic education setting when he/she functions in order to make control, use and protect the sovereignty.

To control the administrators and teachers' behaviours deviating from the norm is again the duty of a supervisor.

\section{Conclusion}

Supervisors who have take part in the supervision system, have important responsibilities to raise individuals who will create a constructive, creative, and distinguished partner of contemporary civilization in the future.

As Bilgen stated the actual purpose is the quality and quantity of education that will be given to each student. Supervision in the Turkish National Education has some problems (Bilgen, 2011, p.272-273):

1. Supervision is a two-parted duty. For this reason, it is inevitable that supervision functions will transform into production in the form of extraordinary truths.

2. The status difference that makes the separation between ministry supervisors and elementary school supervisors attaches opposing forces to the administration process thus breaks up duty integrity.

A supervisor is expected to have an understanding in line with human rights and principles of democracy and exemplify these in her/his behaviours. She/he should be a role model for administrators and teachers. 
While course pass and credit system was implemented in all higher education institutions without any exception, not implementing it in lower levels draws attention to the fundamental variables of system understanding in education.

Human rights and democracy principles have still not been sufficiently established in education settings and intuitions.

If the exemplary value and experience of supervision can be projected to teachers and administrators' at the beginning of their professional career, then the proper supervision procedure will become a complimentary part of professional life. It contributes to the continuous development of teachers and administrators (Hawkins, Shohet, Ryde and Wilmot, 2012, p.3).

Supervision plays a significant role in terms of being open to new learning and clearing up one's acts. Self-awareness and self-confidence are indispensable factors for a teacher's self-development. This is the duty of supervisor (Hawkins, Shohet, Ryde and Wilmot, 2012, p.3).

In order to be a contemporary and democratic society, it is a must to adopt principles of human rights and democracy in daily life and thus to implement the contemporary and democratic education. This implementation is indispensable to create and become a democratic and hence a scientific society.

\section{Suggestions}

Supervision in the context of contemporary and democratic education approach should embed the following recommendations to one's behaviors at least at the lowest level and even at the evaluation level:

1. Education right should be given to everyone without being limited.

2. Everyone should be given opportunities to receive higher education. Because the purpose of education is not to raise only distinguished and skilful individuals but to find ways to develop each individual's competencies.

3. Children with disabilities should be educated in the same classrooms with normal children whenever possible. Options should be sought and applied for students who cannot continue their education. 
4. Instead of suspending students who do not obey school rules and show abnormal behaviours, causes of this situation should be investigated and educational problems of those children should be solved.

5. Education should be a student-centred process. For each student, education program should be prepared. All courses should be elective. Student should be able take as many courses and necessary credits as he/she wishes until become graduated.

6. Grading should be a tool for students to understand their level of success and to fulfil their studies. As a matter of fact grading (meaningless unless standard) should be eliminated.

7. Students' out-of-school success should also be evaluated.

8. Fear and punishment should be substituted for love and respect.

9. Schools should provide students with examples to predict future. Education should develop creativity and scientific thinking power of student.

\section{References}

Aseltine, J. M., Faryniarz, J. O. And Rigazio-DiGilio, A. J. (2006). Supervision for learning: A performance-based approach to teacher development and school improvement. Alexandria, VA.: Association for Curriculum Development.

Aydin, M. (1993). Çă̆daş eğitim denetimi. Ankara: Pegem Personel Eğitim Merkezi Yayınları.

Bilgen, H. N. (2011). Prof. Dr. H. Nihat Bilgen anlatiyor. Pegem Akademi.

Bilgen, H. N. (1997). Yayımlanmamış ders notları. Bolu: AİBÜ.

Bilgen, H. N. (1996, Eylül-Ekim). 21.yüzy1lda eğitim ve öğretmen. Modern ögretmen yetiştirmede gelişme ve ilerlemeler sempozyumu. Ankara: Milli Eğitim Bakanlığı, Hacettepe Üniversitesi Eğitim Fakültesi, Heidelberg Yüksek Öğretmen Okulu ve Alman Kültür Merkezi işbirliği ile düzenlenen sempozyum. 
Bilgen, H. N. (1993). Çağdaş ve demokratik ĕgitim: Ders geçme ve kredi uygulaması. Ankara: Milli Eğitim Bakanlığı Yayınları.

Bilgen, H. N. (1990). Örgüt iklimi: Milli Ĕ̈itim Bakanlı̆̆ Teftiş Kurulu. Ankara: TODAİE Yayınları.

Bilgen, H. N. (1986). İlköğretim okulu araştırması (yönetim boyutu). Ankara: Milli Eğitim Gençlik ve Spor Bakanlığı İlköğretim Genel Müdürlüğü.

Burke, P. and Krey, R. D. (2005). Supervision: A guide to instructional leadership. Springfield: Charles C Thomas Publisher.

Bursalıŏlu, Z. (1994). Okul yönetiminde yeni yapı ve davranış (9. baskı). Ankara: Pegem Yayınları.

Caspi, J. and Reid, W. J. (2012). Educational supervision in social work: A task-centered model for field instruction and staff development. New York: Columbia University Press.

Davys, A. and Beddoe, L. (2010). Best practice in professional supervision: A guide for the helping professions. London: Jessica Kingsley Publishers.

Evans, C. S. (2009). How to be an educational supervisor. In N. Cooper, and K. Forrest, (Eds.), Essential guide to educational supervision in postgraduate medical education (pp. 1-11). Basim Yeri: Wiley-Blackwell Pub./BMJ Books.

Harris, B. M. (1975). Supervisory behavior in education. Prentice-Hall, Inc., Englewood Cliffs, N.J.1963.

Hawkins, P., Shohet, R., Ryde, J. and Wilmot, J. (2012). Supervision in the helping professions. Maidenhead: McGraw-Hill Education.

Henderson, P. (Ed.). (2009a). A different wisdom: Reflections on supervision practice (Vol. 1). London: Karnac Books.

Henderson, P. (Ed.). (2009b). Supervisor training: Issues and approaches: Guide to supervision. London: Karnac Books. 
Marshall, K. (2013). Rethinking teacher supervision and evaluation: How to work smart, build collaboration, and close the achievement gap. John. Wiley \& Sons.

Memduhoğlu, H. B. and Zengin, M. (2012). Çağdaş eğitim denetimi modeli olarak öğretimsel denetimin Türk eğitim sisteminde uygulanabilirliği. Journal of Theoretical Educational Science/Kuramsal Eğitimbilim Dergisi, 5(1), 131-142.

Milli Eğitim Bakanlığı Rehberlik ve Denetim Başkanlığı ile Maarif Müfettişleri Başkanlıkları Yönetmeliği'nde Değişiklik Yapılmasına Dair Yönetmelik. (16 Mart 2016). Resmi Gazete, 29655.

Milli Eğitim Bakanlığı Rehberlik ve Denetim Başkanlığı ile Maarif Müfettişleri Başkanlıkları Yönetmeliği. (24 Mayıs 2014). Resmi Gazete, $652 / 29009$.

Russell, B. (2001). Eğitim üzerine. (N. Bezel,, Çev.). İstanbul: Say Yayınları.

Seçkin, N. (1998). Teftişte yeni bir yaklaşım: Sanatsal teftiş. H. Taymaz and M. Hesapçığlu, (Eds.), Türkiye'de eğitim yönetimi. Prof. Dr. Ziya Bursalıoğlu'na Armăgan içinde (pp.2019-217). İstanbul: Kültür Koleji Eğitim Vakfı Yayınları.

Taymaz, H. (1993). Teftiş: Kavramlar, ilkeler, yöntemler (3. bask1). Ankara: Kadığlu Matbaası.

Wiles, K. (1963). Supervision for better schools. Englewood Cliffs, New Jersey: Prentice-Hall. 